\title{
Identifikasi Kemampuan Pemecahan Masalah Matematika Mahasiswa Calon Guru SD di STKIP Taman Siswa Bima dan Cara Pengembangannya
}

\author{
Anisah $^{1}$, Sri Lastuti ${ }^{2, *}$ \\ ${ }^{1}$ STKIP Taman Siswa Bima, \\ *srilastuti_art13@yahoo.co.id
}

\section{Artikel Info}

Tanggal Publikasi

2019-12-30

Kata Kunci

Pemecahan Masalah

Matematika

Calon Guru SD

\section{Abstrak}

Kemampuan pemecahan masalah matematika merupakan kemampuan seseorang dalam menyelesaikan masalah matematika dengan menggunakan tahap-tahap penyelesaian yang jelas. Kemampuan pemecahan masalah matematika menjadi aspek yng sangat penting bagi seseorang yang belajar matematika mengingat kemampuan pemecahan masalah matematika menjadi salah satu indicator seseorang dikatakan memahami matematika. Namun nyatanya kemampuan tersebut masih menjadi masalah bagi sebagian siswa tidak terkecuali mahasiswa calon guru SD STKIP Taman Siswa Bima. Berdasarkan hal tersebut, tujuan penelitian ini adalah untuk mengidentifikasi kemampuan pemecahan masalah matematika mahasiswa dan mengkaji lebih mendalam dan secara lebih detail sejauh mana tingkat dan level kemampuan pemecahan masalah matematika calon guru SD serta cara mengembangkannya. Penelitian ini dilakukan pada Mahasiswa semester $\mathrm{V}$ kelas A dan Kelas B yang menempuh matakuliah pembelajaran matematika SD kelas awal. Jenis penelitian ini adalah penelitian eksploratif. Dari hasil penelitian diperoleh hasil bahwa 1) kemampuan pemecahan masalah matematika mahasiswa calon guru SD di STKIP Taman Siswa Bima dalam memahami masalah dan membuat rencana penyelesaian berada padakategori tinggi yang artinya sebagian mahasiswa tidak mengalami hambatan pada tahap tersebut. 2) Tahapan yang dianggap paling sulit bagi mahasiswa dalam menyelesaikan masalah matematika adalah pada tahap melaksanakan rencana dan menarik kesimpulan. Cara untuk mengembangkan kemampuan pemecahan masalah matematika adalah 1) mahasiswa harus dibiasakan untuk menyelesaikan soal-soal terbuka dan soal yang mampu merangsang berpikir kritis, 2) memilih metode yang dapat meningkatkan kemampuan pemecahan masalah matematika.

\section{PENDAHULUAN}

Matematika merupakan salah satu mata pelajaran yang memiliki peran penting dalam kehidupan sehari-hari. Salah satu manfaat penting dalam mempelajari matematika adalah melatih berpikir kritis, kreatif, inovatif, sistematis dan terbiasa menyelesaiakan masalah. Mengingat begitu pentingnya matematika, maka perlu dilakukan upaya untuk mengembangkan pembelajaran matematika itu sendiri. Penguatan pembelajaran matematika harus dilakukan dari semua aspek baik pada pemilihan metode pembelajaran yang tepat, evaluasi hasil dan aspek pendidik. Pada aspek pendidik, sebisa mungkin guru matematika harus memiliki kemampuan mengajar yang baik, memahami konsep dengan benar dan memiliki kemampuan memecahkan beberapa persoalan matematika dengan baik. Kompetensi guru sebagai agen pembelajaran pada jenjang pendidikan dasar dan menengah serta pendidikan anak usia dini yang meliputi: kompetensi pedagogik, kepribadian, profesional, dan sosial. Dalam hal keterampilan, seorang guru harus menguasai keterampilan mengajar, yaitu: membuka dan menutup pelajaran, bertanya, memberi penguatan, dan mengadakan variasi mengajar (Saragih, 2016).

Selain keterampilan guru seperti yang disebutkan di atas, salah satu komptensi penting yang harus dimiliki oleh seorang guru adalah kemampuan pemecahan masalah matematika. Menurut Muchlis 
(2012) kemampuan pemecahan masalah merupakan usaha mencari jalan keluar dari suatu kesulitan, mencapai suatu tujuan yang tidak begitu saja dengan mudah dapai dicapai. Selain itu menurut Harahap, ER ( 2017) kemampuan pemecahan masalah matematis merupakan suatu aktivitas kognitif yang kompleks, sebagai proses untuk mengatasi suatu masalah yang ditemui dan untuk menyelesaikannya diperlukan sejumlah strategi. Hal tersebut mengandung arti bahwa kemampuan pemecahan masalah bukan hanya sekedar menyelesaikan soal atau masalah yang diberikan, tetapi juga menjurus pada kemampuan seseorang dalam memilih strategi yang tepat dan efektif dalam menyelesaian masalah. Sejalan dengan pendapat tersebut Anisah (2018) menjelaskan bahwa kemampuan pemecahan masalah matematis merupakan kemampuan seseorang (mahasiswa) dalam menyelesaiakan persoalan matematika sesuai dengan tujuan yang di tetapkan. Lebih lanjut Haryani, D. (2011) menyatakan bahwa dalam pembelajaran matematika dengan pemecahan masalah siswa dituntut untuk menggali dan menunjukkan kemampuan berpikir kritisnya mulai dari memahami masalah, merencanakan pemecahan, melaksanakan rencana pemecahan, dan melihat kembali/mengevaluasi kembali pemecahan masalah yang telah dilaksanakan. Artinya pemecahan masalah merupakan bentuk pembelajaran yang dapat menciptakan ide baru dan menggunakan aturanaturan yang telah dipelajari terdahulu untuk membuat formulasi pemecahan masalah.

Berkenaan dengan hal tersebut dapat disimpulkan bahwa kemampuan pemecahan masalah penting dikembangkan baik kepada siswa terutama untuk calon guru yang akan mengajar matematika nantinya. Calon guru matematika memang sudah seharusnya memiliki kemampuan pemecahan masalah matematika untuk menyiapkan diri sebagai pendidik yang akan mengajar siswanya. Mahasiswa calon guru SD yang nantinya akan mengajar matematika harus cukup mendapatkan kesempatan untuk mengembangkan kemampuannya dalam pemecahan masalah, mengingat termasuk di dalam tugasnya nanti ketika menjadi guru adalah membimbing siswa belajar memecahkan masalah matematika (Widjajanti, D. B., 2009). Kemampuan guru dalam memecahkan masalah matematika akan secara langsung berpengaruh pada siswa karena yang mengajarkan siswa untuk memecahkan masalah matematika adalah guru itu sendiri. Oleh karena itu meningkatkan kemampuan pemecahan masalah bagi mahasiswa calon guru SD juga penting dilakukan mengingat yang akan mentransfer dan mengembangkan kemampuan tersebut adalah seorag guru tersebut.

Namun untuk mengembangkan kemamapuan pemecahan masalah matematika bagi seseorang bukanlah hal yang mudah karena pemecahan masalah merupakan proses mental tingkat tinggi dan memerlukan proses berpikir yang lebih kompleks (Anggo, M, 2011). Ditambah lagi dengan kajian tentang matematika yang begitu abstrak sehingga menjadi kesulitan tersendiri bagi mahasiswa calon guru SD. Mahasiswa calon guru SD berasal dari sekolah yang berbeda-beda, pengalaman belajar dari masing-masing mahasiswa tentunya berbeda-beda. Dan hal tersebut akan mempengaruhi tingkat kemampuan pemecahan masalah matematika mahasiswa berdasarkan pengalaman belajar dan kebiasaan belajar tersebut. Oleh karena itu kajian awal dalam penelitian ini adalah melakukan identifikasi terhadap kemampuan pemecehan masalah matematika mahasiswa calon guru supaya dapat mngetahui tingakt atau level kemampuan pemecahan msalah matematikanya, penyebab rendahnya kemampuan pemecahan msalah, baian-bagian yang menjadi kelemahan mahasiswa dalam mengembangkan kemampua pemecahan masalah serta bagaimana upaya mengembangkan kemampuan pemecahan msalah tersebut.

Penelitian ini bertujuan untuk mengidentifikasi kemampuan pemecahan masalah matematika mahasiswa calon guru SD di STKIP Taman Siswa Bima. Indikator yang digunakan untuk melakukan kajian terhadap kegiatan identifikasi mahasiswa calon guru ini merujuk pada indikator kemampuan pemecahan masalah menurut NCTM (2003) yaitu: (1) Menerapkan dan mengadaptasi berbagai pendekatan dan strategi untuk menyelesaikan masalah, (2) Menyelesaikan masalah yang muncul di dalam matematika atau di dalam konteks lain yang melibatkan matematika, (3) Membangun pengetahuan matematis yang baru lewat pemecahan masalah, dan (4) Memonitor dan merefleksi pada 
proses pemecahan masalah matematis. Adapun sumber kajian ini berasal dari analisis hasil tes beberapa soal matematika yang diselesaikan dengan langkah Polya. Langkah Polya yang dimaksud adalah 1) memahami masalah; 2) membuat perencanaan; 3) melaksanakan rencana; dan 4) melihat kembali pada solusi yang lengkap (Marlina, L., 2013).

Penelitian ini penting dilaksanakan sebagai sebagai langkah awal mengenali potensi kemampuan pemecahan masalah matematika mahasiswa calon guru mengingat guru nantinya memiliki tugas untuk mengembangkan kemampuan pemecahan masalah matematika siswanya. Hasil penelitian ini diharapkan mengahasilkan peta kemampuan pemecahan masalah matematika mahasiswa calon guru SD dan menyajikan cara mengembangkannya.

\section{METODE}

Jenis penelitian yang digunakan dalam penelitian ini adalah penelitian Ekploratif. Penelitian ini dilaksanakan pada mahasiswa calon guru SD STKIP Taman Siswa Bima Kelas A dan kelas B yang menempuh matakuliah pembelajaran matematika SD kelas awal. Hasil tes kemampuan pemecahan masalah matematika mahasiswa dan wawancara dijadikan dasar dalam kesimpulan penelitian ini.

Dalam penelitian ini digunakan beberapa instrumen yang digunakan untuk mengumpulkan data penelitian. Instrumen yang dimaksud adalah tes kemampuan pemecahan masalah matemtia dan lembar wawancara. Data yang digunakan adalah data tes kemampuan pemecahan masalah matematika dan tes wawancara pada mahasiswa calon guru prodi PGSD STKIP Taman Siswa Bima kelas A dan Kelas B pada matakuliah pembelajaran matematika SD kelas awal yang di dalamnya terdapat sub materi bangun ruang sisi datar. Adapun teknik analisis data yang digunakan dalam penelitian ini adalah reduksi data, penyajian data dan penarikan kesimpulan.

Adapun Indikator kemampuan pemecahan masalah matematika berdasarkan langkah Polya di sajikan sebagai berikut:

Tabel 1. Indikator Kemampuan Pemecahan Masalah Matematika berdasarkan Langkah Polya

\begin{tabular}{|c|c|c|}
\hline $\begin{array}{l}\text { Langkah } \\
\text { Ke- }\end{array}$ & Langkah Polya & Indikator \\
\hline $\mathrm{I}$ & Memahami Masalah & $\begin{array}{l}\text { a. Mahasiswa mampu menulis semua informasi-informasi yang } \\
\text { diketahui dalam soal } \\
\text { b. Mahasiswa mengetahui apa yang ditanyakan dalam } \\
\text { permasalahan. } \\
\text { c. Mahasiswa mampu memahami maksud dari permasalahan } \\
\text { yang diberikan. }\end{array}$ \\
\hline II & $\begin{array}{l}\text { Membuat } \\
\text { Perencanaan }\end{array}$ & $\begin{array}{l}\text { a. Mahasiswa mampu menentukan langkah-langkah } \\
\text { penyelesaian permasalahan. } \\
\text { b. Mahasiswa maengetahui strategi pemecahan masalah. }\end{array}$ \\
\hline III & $\begin{array}{l}\text { Melaksanakan } \\
\text { Perencanaan }\end{array}$ & $\begin{array}{l}\text { a. Mahasiswa mampu menggunakan pengalaman belajarnya } \\
\text { untuk menyelesaikan masalah } \\
\text { b. Mahasiswa mampu menyelesaikan soal sesuai langkah- } \\
\text { langkah penyelesaian serta mampu mendeskripsikan } \\
\text { argument terhadap langkah-langkah peneyelesaian masalah. }\end{array}$ \\
\hline IV & Melihat Kembali & $\begin{array}{l}\text { Mahasiswa mampu membuat kesimpulan dari penyesalesaian } \\
\text { soal matematika yang diberikan. }\end{array}$ \\
\hline
\end{tabular}




\section{HASIL DAN PEMBAHASAN}

Tujuan penelitian ini adalah untuk mendeskripsikan kemampuan pemecahan masalah matematika mahasiswa calon guru SD dan mengetahui cara pengembangannya berdasarkan analisis dari hasil temuan-temuan selama penelitian. Identifikasi kemampuan pemecahan masalah tersebut menggunakan soal tes kemampuan pemecahan masalah matematika pada materi bangun ruang sisi datar yang berjumlah 5 soal uraian. Jumlah mahasiswa yang menjadi subjek dalam penelitian ini adalah 33 siswa untuk kelas A dan 35 siswa kelas B sehingga jumlah siswa untuk kedua kelas tersebut sebanyak 68 mahasiswa. Identifikasi dilakukan dengan menganalisis hasil pekerjaan mahasiswa dengan mengedepankan dan memperhatikan langkah Polya dalam penyelesaiannya. Untuk menguatkan data penelitian ini, peneliti juga melakukan wawancara dengan mahasiswa calon guru untuk mengidentifikasi hal-hal yang berkaitan dengan kesulitan mahasiswa dalam menyelesaikan permasalahan yang diberikan.

Hasil kemampuan pemecahan masalah matematika menggunakan Tes kemampua pemecahan masalah matematika dalam bentuk soal uraian sebanyak 5 nomor pada mahasiswa calon guru SD dipaparkan sebagai berikut:

\section{Soal 1 tentang menentukan luas permukaan Kubus dan Prisma.}

Analisis penyelesaian soal siswa yang berhubungan dengan menentukan luas permukaan kubus dan prisma adalah sebagai berikut:

Tabel 2. Identifikasi Hasil Tes Peyelesaian Masalah Soal No.1

\begin{tabular}{|c|c|c|c|}
\hline $\begin{array}{l}\text { Langkah } \\
\text { Ke- }\end{array}$ & Langkah Polya & Indikator & $\begin{array}{c}\text { Identifikasi Penyelesain Soal } \\
\text { Mahasiswa }\end{array}$ \\
\hline I & $\begin{array}{l}\text { Memahami } \\
\text { Masalah }\end{array}$ & $\begin{array}{l}\text { b. Mahasiswa mengetahui apa } \\
\text { yang ditanyakan dalam } \\
\text { permasalahan. } \\
\text { c. Mahasiswa mampu memahami } \\
\text { maksud dari permasalahan } \\
\text { yang diberikan. }\end{array}$ & $\begin{array}{l}64 \text { mahasiswa atau sebesar } 94 \\
\% \text { mahasiswa mampu menulis } \\
\text { semua informasi yang ada } \\
\text { dalam persoalan yang } \\
\text { diberikan. } \\
64 \text { mahasiswa atau sebesar } 94 \\
\% \text { mahasiswa mampu } \\
\text { mengetahui apa yang } \\
\text { ditanyakan dalam soal. } \\
64 \text { mahasiswa atau sebesar } 94 \\
\% \text { mahasiswa mampu } \\
\text { memahami maksud dari } \\
\text { nersoalan vano diberikan. }\end{array}$ \\
\hline II & $\begin{array}{l}\text { Membuat } \\
\text { Perencanaan }\end{array}$ & $\begin{array}{l}\text { a. Mahasiswa mampu } \\
\text { menentukan langkah-langkah } \\
\text { penyelesaian permasalahan. } \\
\text { b. Mahasiswa maengetahui } \\
\text { strategi pemecahan masalah. }\end{array}$ & $\begin{array}{l}70 \% \text { Mahasiswa mampu } \\
\text { menentukan langkah-langkah } \\
\text { penyelesaian permasalahan. } \\
75 \% \text { Mahasiswa mampu } \\
\text { menentukan langkah-langkah } \\
\text { penyelesaian permasalahan. }\end{array}$ \\
\hline III & $\begin{array}{l}\text { Melaksanakan } \\
\text { Perencanaan }\end{array}$ & 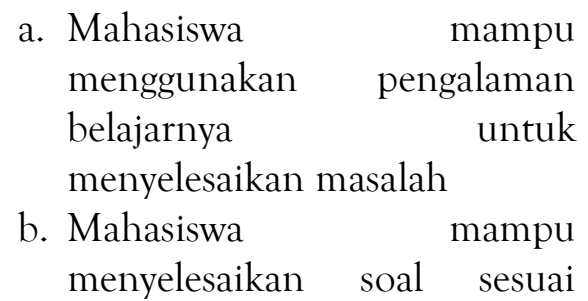 & $\begin{array}{l}65 \% \text { mahasiswa mampu } \\
\text { menggunakan pengalaman } \\
\text { belajarnya r untuk } \\
\text { menyelesaikan masalah } \\
66 \% \text { mahasiswa mampu } \\
\text { menyelesaikan soal sesuai }\end{array}$ \\
\hline
\end{tabular}




\begin{tabular}{|c|c|c|c|}
\hline & & $\begin{array}{l}\text { langkah-langkah penyelesaian } \\
\text { serta mampu mendeskripsikan } \\
\text { argument terhadap langkah- } \\
\text { langkah peneyelesaian masalah } \\
\text { dengan benar. }\end{array}$ & $\begin{array}{l}\text { langkah-langkah penyelesaian } \\
\text { serta mampu } \\
\text { mendeskripsikan argument } \\
\text { terhadap langkah-langkah } \\
\text { peneyelesaian masalah. }\end{array}$ \\
\hline IV & $\begin{array}{l}\text { Melihat } \\
\text { Kembali }\end{array}$ & $\begin{array}{l}\text { Mahasiswa mampu membuat } \\
\text { kesimpulan dari penyesalesaian } \\
\text { soal matematika yang diberikan. }\end{array}$ & $\begin{array}{l}65 \% \text { mahasiswa mampu } \\
\text { membuat kesimpulan dari } \\
\text { penyesalesaian } \\
\text { matematika yang diberikan } \\
\text { meskipun ada yang tidak } \\
\text { tepat. }\end{array}$ \\
\hline
\end{tabular}

Dari Tabel 2 di atas dijelaskan bahwa kemampuan mahasiswa dalam menyelesaikan soal yang berkaitan dengan menentukan luas permukaan kubus dan prisma dengan menggunakan analisis langkah Polya, kemampuan mahasiswa pada tahap memahami masalah dianggap tidak terlalu bermasalah karena tingkat kemampuan mencapai 94\%. Sedangkan pada tahap kedua ada sebagian mahasiswa yang mampu membuat perencanaan dan sebagian yang lain tidak mampu membuat perencanaan dalam menyelesaikan permasalahan.tercatat pada tahap ke II rata-rata kemampuan mahasiswa mencapai $72,5 \%$. Pada tahap melaksanakan perencanaan jumlah mahasiswa rata-rata mencapai $65 \%$. Dan pada tahap akhir terdapat 65\% mahasiswa yang mampu menarik kesimpulan dari penyelesaian keseuruhan soal yang diberikan.

\section{Soal 2. Tentang Menentukan Luas Diagonal Ruang sebuah Balok}

Analisis hasil penyelesaian masalah oleh siswa terkait menentukan luas permukaan balok adalah sebagai berikut:

Tabel 3. Identifikasi Hasil Tes Peyelesaian Masalah Soal No.2

\begin{tabular}{|c|c|c|c|}
\hline $\begin{array}{l}\text { Langkah } \\
\text { Ke- }\end{array}$ & Langkah Polya & Indikator & $\begin{array}{c}\text { Identifikasi Penyelesain Soal } \\
\text { Mahasiswa }\end{array}$ \\
\hline \multirow[t]{3}{*}{ I } & \multirow[t]{3}{*}{$\begin{array}{l}\text { Memahami } \\
\text { Masalah }\end{array}$} & $\begin{array}{l}\text { a. Mahasiswa mampu menulis } \\
\text { semua informasi-informasi yang } \\
\text { diketahui dalam soal }\end{array}$ & $\begin{array}{l}54 \text { mahasiswa atau sebesar } 79 \\
\text { \% mahasiswa mampu menulis } \\
\text { semua informasi yang ada } \\
\text { dalam persoalan yang } \\
\text { diberikan. }\end{array}$ \\
\hline & & $\begin{array}{l}\text { b. Mahasiswa mengetahui apa yang } \\
\text { ditanyakan dalam permasalahan. }\end{array}$ & $\begin{array}{l}54 \text { mahasiswa atau sebesar } 79 \\
\% \text { mahasiswa mengetahui apa } \\
\text { yang ditanyakan dalam soal. }\end{array}$ \\
\hline & & $\begin{array}{l}\text { c. Mahasiswa mampu memahami } \\
\text { maksud dari permasalahan yang } \\
\text { diberikan. }\end{array}$ & $\begin{array}{l}54 \text { mahasiswa atau sebesar } 79 \\
\% \text { mahasiswa mampu } \\
\text { memahami permaslaahan yang } \\
\text { diberikan. }\end{array}$ \\
\hline II & $\begin{array}{l}\text { Membuat } \\
\text { Perencanaan }\end{array}$ & $\begin{array}{l}\text { a. Mahasiswa mampu menentukan } \\
\text { langkah-langkah penyelesaian } \\
\text { permasalahan. }\end{array}$ & $\begin{array}{l}53 \% \text { mahasiswa mampu } \\
\text { menentukan langkah-langkah } \\
\text { penyelesaian permasalahan. }\end{array}$ \\
\hline & & $\begin{array}{l}\text { b. Mahasiswa maengetahui strategi } \\
\text { pemecahan masalah. }\end{array}$ & $\begin{array}{l}55 \% \text { Mahasiswa mampu } \\
\text { menentukan } \\
\text { penyelesaian permasalahan. }\end{array}$ \\
\hline III & $\begin{array}{l}\text { Melaksanakan } \\
\text { Perencanaan }\end{array}$ & $\begin{array}{l}\text { a. Mahasiswa } \\
\text { menggunakan }\end{array}$ & $\begin{array}{l}60 \% \text { mahasiswa mampu } \\
\text { menggunakan pengalaman }\end{array}$ \\
\hline
\end{tabular}




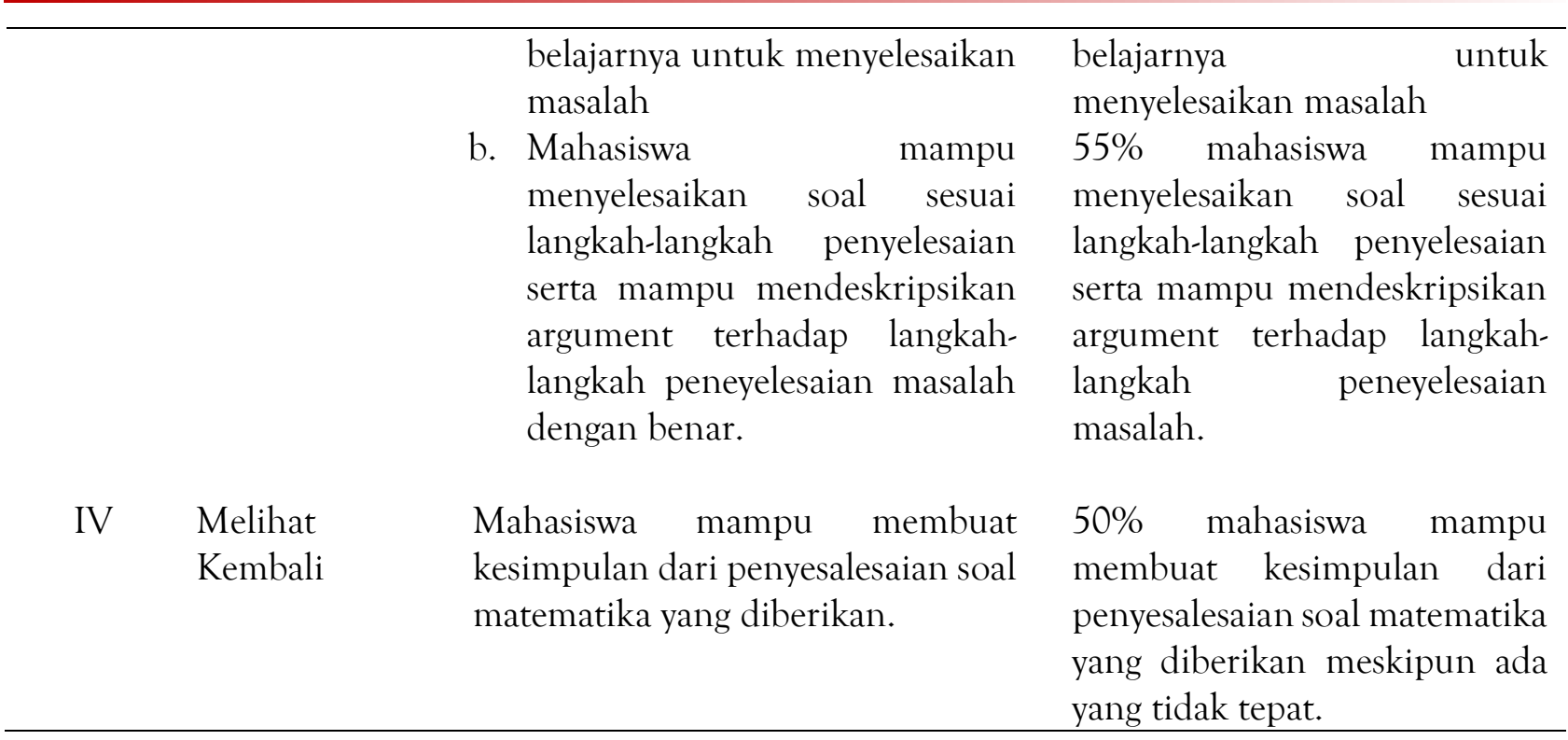

Dari Tabel 3 di atas dijelaskan bahwa kemampuan mahasiswa dalam menyelesaikan soal tentang menentukan luas diagonal ruang sebuah balok dengan menggunakan analisis langkah Polya, pada tahap memahami masalah dianggap tidak terlalu bermasalah karena tingkat kemampuan mencapai 74\%. Sedangkan pada tahap kedua ada sebagian mahasiswa yang mampu membuat perencanaan dan sebagian yang lain tidak mampu membuat perencanaan dalam menyelesaikan permasalahan.tercatat pada tahap ke II rata-rata kemampuan mahasiswa mencapai 57.5\%. Pada tahap melaksanakan perencanaan jumlah mahasiswa rata-rata mencapai 50\%. Dan pada tahap akhir hanya $40 \%$ mahasiswa yang mampu menarik kesimpulan dari penyelesaian keseuruhan soal yang diberikan.

Soal 3. Tentang Menentukan tinggi Limas jika diketahui luas alasnya dan panjang rusuk-rusuknya

Analisis hasil pekerjaan soal siswa terkait menentukan tinggi Limas adalah sebagai berikut:

Tabel 4. Identifikasi Hasil Tes Peyelesaian Masalah Soal No.3

\begin{tabular}{|c|c|c|c|}
\hline $\begin{array}{l}\text { Langk } \\
\text { ah Ke- }\end{array}$ & $\begin{array}{l}\text { Langkah } \\
\text { Polya }\end{array}$ & Indikator & $\begin{array}{c}\text { Identifikasi Penyelesain Soal } \\
\text { Mahasiswa }\end{array}$ \\
\hline I & $\begin{array}{l}\text { Memahami } \\
\text { Masalah }\end{array}$ & $\begin{array}{l}\text { b. Mahasiswa mengetahui apa yang } \\
\text { ditanyakan dalam } \\
\text { permasalahan. } \\
\text { c. Mahasiswa mampu memahami } \\
\text { maksud dari permasalahan yang } \\
\text { diberikan. }\end{array}$ & $\begin{array}{l}55 \text { mahasiswa atau sebesar } 80 \% \\
\text { mahasiswa mampu menulis semua } \\
\text { informasi yang ada dalam persoalan } \\
\text { yang diberikan. } \\
56 \text { mahasiswa atau sebesar } 82 \% \\
\text { mahasiswa mengetahui apa yang } \\
\text { ditanyakan dalam soal. } \\
54 \text { mahasiswa atau sebesar } 79 \% \\
\text { mahasiswa mampu memahami } \\
\text { maksud dari permasalahan yang } \\
\text { diberika. }\end{array}$ \\
\hline II & $\begin{array}{l}\text { Membuat } \\
\text { Perencanaan }\end{array}$ & $\begin{array}{l}\text { a. Mahasiswa } \quad \text { mampu } \\
\text { menentukan langkah-langkah } \\
\text { penyelesaian permasalahan. }\end{array}$ & $\begin{array}{l}50 \% \text { Mahasiswa mampu } \\
\text { menentukan langkah-langkah } \\
\text { penyelesaian permasalahan. }\end{array}$ \\
\hline & & $\begin{array}{l}\text { a. Mahasiswa maengetahui strategi } \\
\text { pemecahan masalah. }\end{array}$ & $\begin{array}{l}\text { 47\% Mahasiswa mampu } \\
\text { menentukan langkah-langkah } \\
\text { penyelesaian permasalahan. }\end{array}$ \\
\hline
\end{tabular}




\begin{tabular}{|c|c|c|c|}
\hline \multirow[t]{2}{*}{ III } & $\begin{array}{l}\text { Melaksanaka } \\
\mathrm{n} \\
\text { Perencanaan }\end{array}$ & $\begin{array}{lr}\text { a. } & \text { Mahasiswa } \\
\text { menggunakan } & \text { pengalampu } \\
\text { belajarnya } & \text { untuk } \\
\text { menyelesaikan masalah } & \end{array}$ & 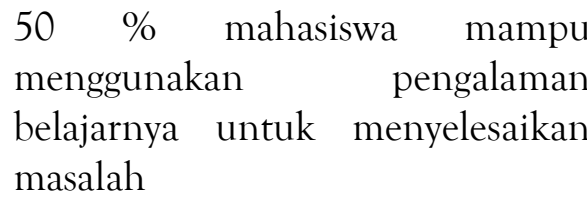 \\
\hline & & $\begin{array}{l}\text { b. Mahasiswa mampu } \\
\text { menyelesaikan soal sesuai } \\
\text { langkah-langkah penyelesaian } \\
\text { serta mampu mendeskripsikan } \\
\text { argument terhadap langkah- } \\
\text { langkah peneyelesaian masalah } \\
\text { dengan benar. }\end{array}$ & $\begin{array}{l}45 \% \text { mahasiswa mampu } \\
\text { menyelesaikan soal sesuai langkah- } \\
\text { langkah penyelesaian serta mampu } \\
\text { mendeskripsikan argument } \\
\text { terhadap langkah-langkah } \\
\text { peneyelesaian masalah. }\end{array}$ \\
\hline IV & $\begin{array}{l}\text { Melihat } \\
\text { Kembali }\end{array}$ & $\begin{array}{l}\text { Mahasiswa mampu membuat } \\
\text { kesimpulan dari penyesalesaian } \\
\text { soal matematika yang diberikan. }\end{array}$ & $\begin{array}{l}45 \% \text { mahasiswa mampu membuat } \\
\text { kesimpulan dari penyesalesaian } \\
\text { soal matematika yang diberikan } \\
\text { meskipun ada yang tidak tepat. }\end{array}$ \\
\hline
\end{tabular}

Dari Tabel 4 di atas dijelaskan bahwa kemampuan mahasiswa dalam menyelesaikan soal yang berkaitan dengan Menentukan tinggi Limas jika diketahui luas alasnya dan panjang rusuk-rusuknya dengan menggunakan analisis langkah Polya, kemampuan mahasiswa pada tahap memahami masalah dianggap tidak terlalu bermasalah karena tingkat kemampuan mencapai 80\%. Sedangkan pada tahap II, III dan ke IV rata-ratanya berturut-turut adalah $48.5 \%$, 47.5\% dan $45 \%$. Kemampuan mahasiswa dalam menyelesaikan soal nomor 2 ini tidak terlalu tinggi.

\section{Soal 4 Tentang Menentukan Luas Permukaan dan Volume Balok}

Analisis hasil pekerjaan soal siswa dalam menentuka Luas permukaan dan volume Balok adalah sebagai berikut:

Tabel 5. Identifikasi Hasil Tes Peyelesaian Masalah Soal No.4

\begin{tabular}{|c|c|c|c|}
\hline $\begin{array}{l}\text { Langk } \\
\text { ah Ke- }\end{array}$ & $\begin{array}{l}\text { Langkah } \\
\text { Polya }\end{array}$ & Indikator & $\begin{array}{c}\text { Identifikasi Penyelesain Soal } \\
\text { Mahasiswa }\end{array}$ \\
\hline I & $\begin{array}{l}\text { Memahami } \\
\text { Masalah }\end{array}$ & $\begin{array}{l}\text { a. Mahasiswa mampu menulis } \\
\text { semua informasi-informasi yang } \\
\text { diketahui dalam soal } \\
\text { b. Mahasiswa mengetahui apa yang } \\
\text { ditanyakan dalam } \\
\text { permasalahan. } \\
\text { c. Mahasiswa mampu memahami } \\
\text { maksud dari permasalahan yang } \\
\text { diberikan. }\end{array}$ & $\begin{array}{l}59 \text { mahasiswa atau sebesar } 86 \% \\
\text { mahasiswa mampu menulis semua } \\
\text { informasi yang ada dalam } \\
\text { persoalan yang diberikan. } \\
59 \text { mahasiswa atau sebesar } 86 \% \\
\text { mahasiswa mampu mengetahui apa } \\
\text { yang ditanyakan dalam soal. } \\
59 \text { mahasiswa atau sebesar } 86 \% \\
\text { mahasiswa mampu memahami } \\
\text { maksud dari persoalan yang } \\
\text { diberkan. }\end{array}$ \\
\hline II & $\begin{array}{l}\text { Membuat } \\
\text { Perencanaan }\end{array}$ & $\begin{array}{l}\text { a. Mahasiswa mampu } \\
\text { menentukan langkah-langkah } \\
\text { penyelesaian permasalahan. } \\
\text { b. Mahasiswa maengetahui strategi } \\
\text { pemecahan masalah. }\end{array}$ & $\begin{array}{l}60 \% \text { Mahasiswa mampu } \\
\text { menentukan langkah-langkah } \\
\text { penyelesaian permasalahan. } \\
55 \% \text { Mahasiswa mampu } \\
\text { menentukan langkah-langkah } \\
\text { penyelesaian permasalahan. }\end{array}$ \\
\hline
\end{tabular}




\begin{tabular}{|c|c|c|c|}
\hline \multirow[t]{2}{*}{ III } & \multirow[t]{2}{*}{$\begin{array}{l}\text { Melaksanaka } \\
\mathrm{n} \\
\text { Perencanaan }\end{array}$} & $\begin{array}{l}\text { a. Mahasiswa mampu } \\
\text { menggunakan pengalaman } \\
\text { belajarnya untuk menyelesaikan } \\
\text { masalah }\end{array}$ & $\begin{array}{l}\text { a. } \quad 50 \% \text { mahasiswa mampu } \\
\text { menggunakan } \\
\text { belajarnya untuk mengalaman } \\
\text { masalah }\end{array}$ \\
\hline & & $\begin{array}{l}\text { b. Mahasiswa mampu } \\
\text { menyelesaikan soal sesuai } \\
\text { langkah-langkah penyelesaian } \\
\text { serta mampu mendeskripsikan } \\
\text { argument terhadap langkah- } \\
\text { langkah peneyelesaian masalah } \\
\text { dengan benar. }\end{array}$ & $\begin{array}{l}50 \% \text { mahasiswa mampu } \\
\text { menyelesaikan soal sesuai langkah- } \\
\text { langkah penyelesaian serta mampu } \\
\text { mendeskripsikan argument } \\
\text { terhadap langkah-langkah } \\
\text { peneyelesaian masalah. }\end{array}$ \\
\hline IV & $\begin{array}{l}\text { Melihat } \\
\text { Kembali }\end{array}$ & $\begin{array}{l}\text { Mahasiswa mampu membuat } \\
\text { kesimpulan dari penyesalesaian } \\
\text { soal matematika yang diberikan. }\end{array}$ & $\begin{array}{l}54 \% \text { mahasiswa mampu membuat } \\
\text { kesimpulan dari penyesalesaian } \\
\text { soal matematika yang diberikan } \\
\text { meskipun ada yang tidak tepat. }\end{array}$ \\
\hline
\end{tabular}

Dari Tabel 5 di atas dijelaskan bahwa kemampuan mahasiswa dalam menyelesaikan soal yang berkaitan dengan menentukan luas permukan dan volume balok dengan menggunakan analisis langkah Polya tercatat sebagai berikut: Tahap I sebanyak $86 \%$, tahap II 57.5\%, tahap III 50\% dan tahap IV adalah 54\%.

\section{Soal 5 Tentang Menentukan Volume Prisma.}

Analisis hasil pekerjaan soal siswa terkait menentukan volume prisma segitiga adalah sebagai berikut:

Tabel 6. Identifikasi Hasil Tes Peyelesaian Masalah Soal No.5

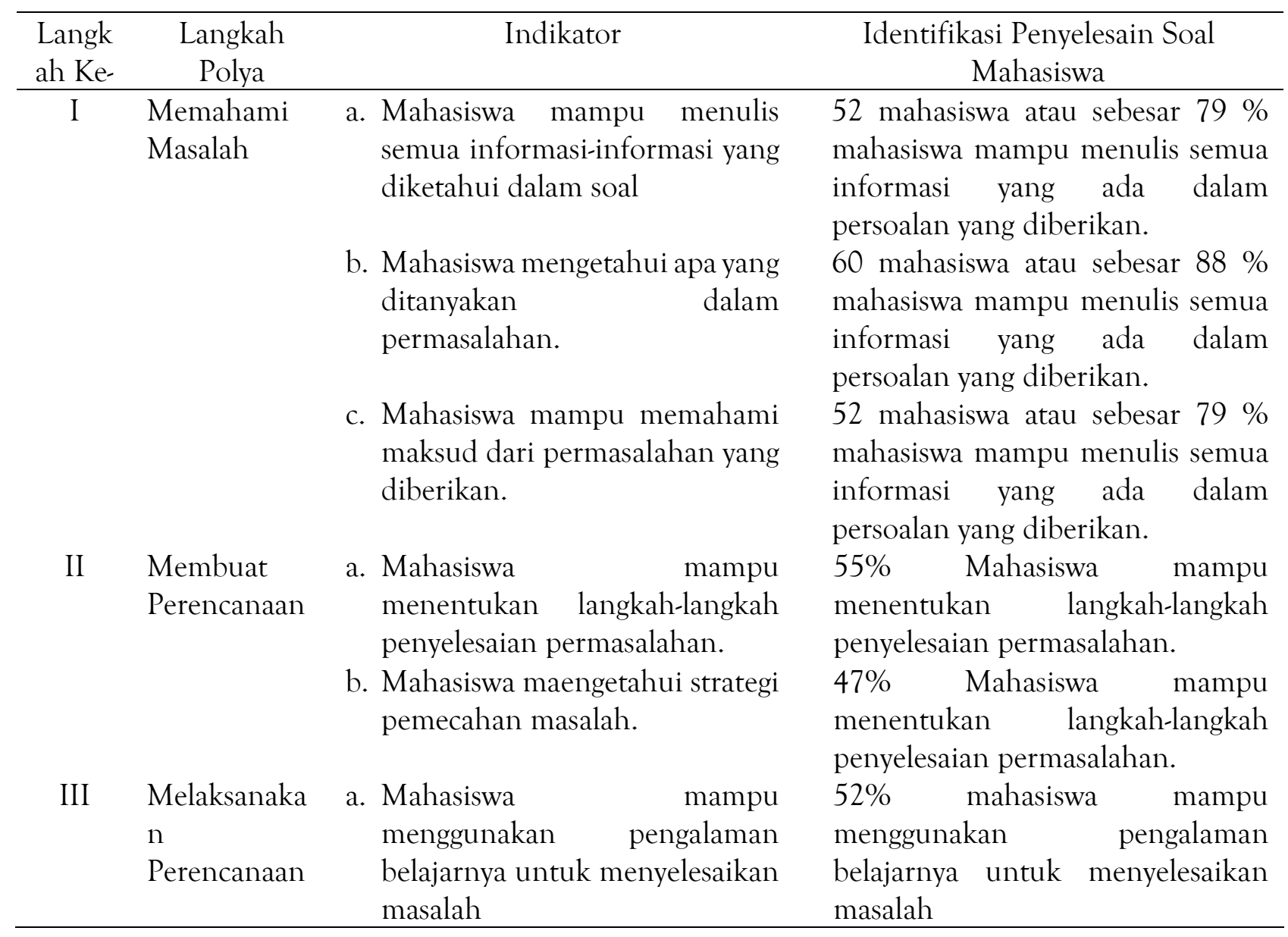




\begin{tabular}{|c|c|c|c|}
\hline & & $\begin{array}{lr}\text { b. Mahasiswa } & \text { mampu } \\
\text { menyelesaikan soal sesuai } \\
\text { langkah-langkah penyelesaian } \\
\text { serta mampu mendeskripsikan } \\
\text { argument terhadap langkah- } \\
\text { langkah peneyelesaian masalah } \\
\text { dengan benar. }\end{array}$ & $\begin{array}{l}49 \% \quad \text { mahasiswa mampu } \\
\text { menyelesaikan soal sesuai langkah- } \\
\text { langkah penyelesaian serta } \\
\text { mampu mendeskripsikan } \\
\text { argument terhadap langkah- } \\
\text { langkah peneyelesaian masalah. }\end{array}$ \\
\hline IV & $\begin{array}{l}\text { Melihat } \\
\text { Kembali }\end{array}$ & $\begin{array}{l}\text { Mahasiswa mampu membuat } \\
\text { kesimpulan dari penyesalesaian } \\
\text { soal matematika yang diberikan. }\end{array}$ & $\begin{array}{l}49 \% \text { mahasiswa mampu membuat } \\
\text { kesimpulan dari penyesalesaian } \\
\text { soal matematika yang diberikan } \\
\text { meskipun ada yang tidak tepat. }\end{array}$ \\
\hline
\end{tabular}

Dari Tabel 6 di atas dijelaskan bahwa kemampuan mahasiswa dalam menyelesaikan soal yang berkaitan Menentukan volume prisma segitiga dengan menggunakan analisis langkah Polya, kemampuan mahasiswa pada tahap memahami masalah dianggap tidak terlalu bermasalah karena tingkat kemampuan mencapai $82 \%$. Sedangkan pada tahap kedua ada sebagian mahasiswa yang mampu membuat perencanaan dan sebagian yang lain tidak mampu membuat perencanaan dalam menyelesaikan permasalahan. Tercatat pada tahap ke II rata-rata banyaknya mahasiswa mencapai 51\%. Pada tahap melaksanakan perencanaan jumlah mahasiswa rata-rata mencapai 50.5\%. Dan pada tahap akhir terdapat $49 \%$ mahasiswa yang mampu menarik kesimpulan dari penyelesaian keseuruhan soal yang diberikan.

\section{Identifikasi Kemampuan Pemecahan Masalah Matematika Mahasiswa Calon Guru SD.}

Berdasarkan hasil pembahasan banyaknya jumlah mahasiswa yang dapat menyelesaikan soal-soal matematika dari semua soal yang diberikan dapat di uraikan sebagai berikut:

Tabel 7. Rata-rata Jumlah Mahasiswa Matematika Berdasarkan Langkah Polya

\begin{tabular}{lccccc}
\hline \multicolumn{1}{c}{ Langkah Polya } & Soal I & Soal II & Soal III & Soal IV & Soal V \\
\hline Memahami Masalah & 94 & 74 & 80 & 86 & 82 \\
Membuat Perencanaan & 72,5 & 57,5 & 48,5 & 57.5 & 51 \\
Melaksanakan Perencanaan & 65 & 50 & 47,5 & 50 & 50,5 \\
Melihat Kembali & 65 & 40 & 45 & 54 & 49 \\
\hline
\end{tabular}

Dari Tabel 7 di atas dijelaskan bahwa kemampuan pemecahan masalah matematika mahasiswa calon guru pada tahap I berada pada kategori tinggi. Hampir semua mahasiswa tidak memiliki hambatan dalam memahami masalah yaitu menuliskan semua informasi dalam soal, mengetahui apa yang ditanyakan dalam soal dan memahami maksud dari permasalahan yang diberikan. Sedangkan untuk langkah kedua yaitu membuat perencanaan rata-rata masih di atas $50 \%$. Begitu juga untuk tahap melaksanakan perencanaan dan melihat kembali. Secara lengkap rata-rata hasil untuk semua soal disajikan sebagai berikut:

Tabel 8. Rata-rata Jumlah Mahasiswa Matematika Berdasarkan Langkah Polya

\begin{tabular}{clc}
\hline $\begin{array}{c}\text { Langkah } \\
\text { Ke- }\end{array}$ & \multicolumn{1}{c}{ Langkah Polya } & $\begin{array}{c}\text { Rata-rata Jumlah Siswa } \\
(\%)\end{array}$ \\
\hline I & Memahami Masalah & 83,2 \\
II & Membuat Perencanaan & 56,2 \\
III & Melaksanakan Perencanaan & 52,6 \\
IV & Melihat Kembali & 50,6 \\
\hline
\end{tabular}


Pengembangan Kemampuan Pemecahan Masalah Matematika Mahasiswa Calon Guru SD.

Untuk mengukur kemampuan pemecahan masalah matematika mahasiswa calon guru digunakan tes yang berisi 5 soal dalam bentuk uraian. Dari soal tersebut mahasiswa menyelesaikannya dengan menggunakan langkah Polya. Dari soal tersebut diperoleh informasi bahwa pada tahap I mahasiswa tidak memiliki banyak hambatan dalam mengidentifikasi informasi-informasi yang ada dalam soal mahasiswa juga tidak memiiki kendala dalam menuliskan apa yang ditanyakan dalam soal. Untuk tahap perencanaan, hanya sebanyak 56, 2 \% mahasiswa yang mampu membuat rencana penyelsaian soal. Lebih lanjut bertambah sedikit jumlah mahasiswa yang mampu menyelesaikan soal dengan menggunakan teknik yang sudah direncanakan tersebut. Dan tercatat hanya 50,6 \% hanya 50,6 $\%$.

Berdasarkan hal tersebut dapat dijelaskan bahwa kemampuan pemecahan masalah matematika masih belum maksimal. Dan tahap yang dianggap paling sulit bagi mahasiswa adalah pada tahap melaksanakan rencana dan menarik kesimpulan.

Setelah mendaptkan data di atas, peneliti melakukan wawancara pada mahasiswa calo guru untuk mendapatkan informasi mendalam berkaitan dengan pada tahap mana kesulitan mahasiswa dalam menyelsaikan masalah dan apa saja hambatan mahasiswa dalam menyelesaikan masalah. Berdasarkan hasil wawancara diperoleh informasi bahwa mahasiswa memiliki kesulitan dalam merencanakan penyelesaian soal, dan berimbas pada kemampuan mahasiswa dalam melaksanakan perencanaan dan penarikan kesimpulan. Hal tersebut diakibatkan karena mahasiswa tidak terbiasa menyesaikan masalah yang menggunakan cara yang sistematis. Hal lain juga yang turut menyebabkan adanya kesulitan mahasiswa dalam menyesaikan masalah menggunakan tahap Polya adalah pengalaman belajar yang rendah. Mahasiswa tidak mampu menggunakan pengalaman belajarnya dalam menyelesaikan masalah.

Berdasarkan masalah dan hambatan mahasiswa calon guru dalam menyelesaikan masalah matematika maka cara-cara yang dapat dilakukan adalah 1) tingkat kesulitan paling tinggi bagi mahasiswa calon guru adalah pada tahap melaksanakan rencana dan menarik kesimpulan oleh karena itu mahasiswa harus dibiasakan meyelesaikan masalah dengan menggunakan strategi pemecahan masalah yang fokus mengembangkan kemampuan menyelesaikan masalah dan menarik kesimpulan, 2) Dosen harus memilih metode yang mampu merangsang kemampuan pemecahan masalah matematika seperti Pembelajaran berbasis masalah (PBL), pembelajaran kontekstual, Model Problem Solving, Inkuiri, Open Endeed dan metode-metode lain yang dapat merangsang berpikir kritis mahasiswa (Sumartini, 2016, Kurniawan, R (2011), Affandi A (2013), Alhadad, S.F. (2010) . 3) Dosen harus mampu mengembangkan soal-soal terbuka, 4) baik mahasiswa maupun dosen harus membiasakan diskusi, sharing pengetahuan, wawasan, dan pengalaman antar dosen mata kuliah yang sama dapat menjadi solusi untuk kendala-kendala yang di hadapi.

\section{PENUTUP}

Kemampuan pemecahan masalah matematika mahasiswa calon guru SD di STKIP Taman Siswa Bima dalam memahami masalah dan membuat rencana penyelesaian berada padakategori tinggi yang artinya sebagian mahasiswa tidak mengalami hambatan pada tahap tersebut. Dan tahap yang dianggap paling sulit bagi mahasiswa dalam menyelesaikan masalah adalah pada tahap melaksanakan rencana dan menarik kesimpulan. Cara untuk mengembangkan kemampuan pemecahan masalah matematika adalah mahasiswa harus dibiasakan untuk menyelesaikan soal-soal terbuka dan soal yang mampu merangsang berpikir kritis, memilih metode yang dapat meningkatkan kemampuan pemecahan masalah matematika seperti PBL, CTL, model problem solving, Inkuiri, Open Endeed, dll. 


\section{Daftar Pustaka}

Afandi, A. (2013). Pendekatan open-ended dan inkuiri terbimbing ditinjau dari kemampuan pemecahan masalah dan representasi multipel matematis. PYTHAGORAS: Jurnal Pendidikan Matematika, 8(1), 1-11.

Alhadad, S. F. (2010). Meningkatkan kemampuan representasi multipel matematis, pemecahan masalah matematis, dan self esteem siswa SMP melalui pembelajaran dengan pendekatan open ended (Doctoral dissertation, Universitas Pendidikan Indonesia).

Anggo, M. (2011). Pelibatan metakognisi dalam pemecahan masalah matematika. Edumatica: Jurnal Pendidikan Matematika.

Anisah, A., \& Lastuti, S. (2018). Pengembangan Bahan Ajar berbasis HOTS untuk Meningkatkan Kemampuan Pemecahan Masalah Matematis Mahasiswa. Kreano, Jurnal Matematika KreatifInovatif, 9(2), 191-197.

Harahap, E. R., \& Surya, E. (2017). Kemampuan Pemecahan Masalah Matematis Siswa Kelas VII Dalam Menyelesaikan Persamaan Linear Satu Variabel.

Haryani, D. (2011). Pembelajaran matematika dengan pemecahan masalah untuk menumbuhkembangkan kemampuan berpikir kritis siswa. In Prosiding Seminar Nasional Penelitian, Pendidikan dan Penerapan MIPA, Fakultas MIPA, Universitas Negeri Yogyakarta (Vol. 14).

Kurniawan, R. (2011). Peningkatan Kemampuan Pemahaman dan Pemecahan Masalah Matematis melalui Pembelajaran dengan Pendekatan Kontekstual pada Siswa Sekolah Menengah Kejuruan No Panggil D MAT KUR p-2010 (Doctoral dissertation, Universitas Pendidikan Indonesia).

Marlina, L. (2013). Penerapanlangkah Polya dalam Menyelesaikan Soal Cerita Keliling dan Luas Persegipanjang. Jurnal Elektronik Pendidikan Matematika Tadulako, 1(1).

Muchlis, E. E. (2012). Pengaruh pendekatan pendidikan matematika realistik indonesia (PMRI) terhadap perkembangan kemampuan pemecahan masalah siswa kelas II SD Kartika 1.10 Padang. Exacta, 10(2), 136-139.

Saragih, A. H. (2008). Kompetensi minimal seorang guru dalam mengajar. Jurnal Tabularasa, 5(1), 23. 34.

Sumartini, T. S. (2016). Peningkatan kemampuan pemecahan masalah matematis siswa melalui pembelajaran berbasis masalah. Mosharafa: Jurnal Pendidikan Matematika, 5(2), 148-158.

Widjajanti, D. B. (2009, December). Kemampuan pemecahan masalah matematis mahasiswa calon guru matematika: apa dan bagaimana mengembangkannya. In Seminar Nasional Matematika dan Pendidikan Matematika (Vol. 5). 